\title{
Online Module for Acid and Base Topic Based on 5E Model
}

https://doi.org/10.3991/ijim.v15i23.27407

\author{
Nurul Nazatul Shahizah Mahamd Shobri, Johari Surif, Nor Hasniza Ibrahim( ${ }^{(凶)}$, \\ Wimbi Apriwanda Nursiwan, Muhammad Abd Hadi Bunyamin \\ Universiti Teknologi Malaysia, Johor Bahru, Malaysia \\ p-norhaniza@utm.my
}

\begin{abstract}
Alternative conception or misconception is one of the problems that often be experienced by the students in science subjects including chemistry due to its abstractness and wide scope to be learned. Previous studies found that students often have misconceptions on strength of acid and base topic such as misconception in determining factor that affect the strength of acid and base, differences between strong and weak acid and base as well as the effect of strength of acid and base on conductivity. To overcome these misconceptions, an online teaching and learning module using $5 \mathrm{E}$ instructional model was developed. Analysis, Design, Development, Implementation and Evaluation (ADDIE) model is used for research and development. The module used interactive tools and medias to make students being active and understand chemistry well. This module was validated by five experts in term of module objectives, module content, usability, flexibility, learning activities and language aspects with average is ninety percent. The results prove that the module is very good and has high validity Therefore, the application of online module for acid and base topic based on $5 \mathrm{E}$ (Engage, Explore, Explain, Elaborate, Evaluate) model is suitable to be implemented in online teaching and learning process.
\end{abstract}

Keywords - strength of acid and base, ADDIE model, 5E, teaching and learning module, online

\section{$1 \quad$ Introduction}

Science subjects especially chemistry is a difficult subject due to its abstractness as it not only involves macroscopic level, but also microscopic level. This leads students to have misconception or alternative conception on chemistry concepts. Meaningful learning cannot be achieved as students cannot relate new knowledge with their prior knowledge or conception. Many studies have been conducted to determine the misconceptions among students on chemistry concepts. Acid and base topic is a topic in chemistry that students often have misconceptions because it is difficult to conceptualize [1]. The subtopics in acid and base includes chemical properties, role of water to show properties of acids and alkali, $\mathrm{pH}$ scale, strength and concentration of acid and alkali 
as well as neutralization. To overcome the misconceptions in chemistry topics, many instructional models are implemented in classroom.

$5 \mathrm{E}$ Model is an example of instructional approach of constructivist learning theory where students construct their own knowledge and understanding about scientific concepts by exploring it [2]. In this model, students are participating actively in the learning process which can results in meaningful learning. This learning model also contributes to enhancement of critical thinking skills and increase of motivation to learn [1], [3]. There are 5 phases in 5E instructional model which consists of Engage, Explore, Explain, Elaborate and Evaluate. In this module, learning activities developed are to be conducted online.

\subsection{Problem background}

In acid and base topic, students often have alternative conception in strength of acid and base concept as reported in several studies. The alternative conception for concept strength of acid and base are in determining factor that affect the strength of acid and base. According to [4], students consider concentration of hydronium ion, $\mathrm{H}_{3} \mathrm{O}^{+}$to determine whether it is strong or weak acid and concentration of hydroxide ion, $\mathrm{OH}^{-}$to determine whether it is strong or weak base. Students also consider weak acid and base have lower number of ions compared to strong acid and base [5]. Another misconception is that students unable to differentiate between strong and weak acid and base [5-6]. Students define strong acids as concentrated acids and weak acids as diluted acids. Reactivity of an acid and base is affected by their strength is another misconception [7]. The last alternative conception that students often had is the effect of strength of acid and base on conductivity where students consider only strong acid can conduct electricity [1], [5], [8].

By knowing the students' misconceptions, teacher can design a teaching method that eliminate the misconceptions. A lesson can be considered effective if it can fix the misconception of chemistry concepts experienced by the students. Therefore, this module is developed to aid the students in overcoming their misconception about the concept of strength of acid and base. $5 \mathrm{E}$ instructional model is chosen to be implemented in this module to overcome these misconceptions. In this module, learning activities developed are to be conducted online. The use of module during online learning is effective potentially, such as the activities provided make students being active, which is appropriate technique [9].

\subsection{Significance of strength of acid and base topic}

Strength of acid and base is a topic in chemistry that hold a great importance not only in scientific laboratory, but also essential in industry and in our daily life. For instance, in industry sulphuric acid is a commonly used in fertilizer manufacturing, waste water processing and to make man-made fibers. Natrium hydroxide which is base and known as caustic soda is used in fabrics, paper and cleaning agents' production. In our daily life, strong acid is found in stomach digestive juice to digest food and $\mathrm{pH}$ levels in the body need to balance. Weak acid such as carbonic acid is found in sea water and soft 
drinks. Most of the products used in our daily life will lose its purpose without acid and base. Organic chemistry reactions also occur through acid and base reaction [10]. Therefore, the understanding of this topic must be enhanced and has correct conception of strength of acid and base. Understanding in acid and base topic will allow us to make use of its advantages, prevent dangers and be able to conduct safety measure.

\subsection{Objectives of study}

The objectives of this study are to develop online module for acid and base topic based on $5 \mathrm{E}$ model, and to identify the suitability of the online module for acid and base topic based on $5 \mathrm{E}$ model.

\section{Methodology}

In this study, a qualitative approach is employed and the module is developed by applying ADDIE Instructional Model which consists of five phases: analysis, design, development, implementation and evaluation as shown in Table 1. This instructional model is used because it provides structured guidelines for designing and developing a learning experience which is module in this study [11].

Table 1. The application of ADDIE in online module for acid and base topic based on 5E model

\begin{tabular}{|l|l|}
\hline \multicolumn{1}{|c|}{ ADDIE Phase } & \multicolumn{1}{c|}{ Activity } \\
\hline Analysis & $\begin{array}{l}\text { Problems experienced by students in learning chemistry are analyzed through } \\
\text { previous literatures using content analysis technique. } \\
\text { Based on the analysis, it is found that student often have alternative conception in } \\
\text { strength of acid and base topic. }\end{array}$ \\
\hline Design & $\begin{array}{l}\text { Planning on development of teaching and learning module for strength of acid and } \\
\text { base topic that implement 5E model which focus on online class. }\end{array}$ \\
\hline Development & $\begin{array}{l}\text { Developing online module for acid and base topic based on 5E model. } \\
\text { Expert assessment will be implemented to ensure suitability of the module. }\end{array}$ \\
\hline Implement & $\begin{array}{l}\text { Online module for acid and base topic based on 5E model is expected to be utilized at } \\
\text { secondary school by chemistry teacher. }\end{array}$ \\
\hline Evaluation & $\begin{array}{l}\text { The effectiveness of the module will be evaluated by the experts. } \\
\text { Validation results obtained and suggestion on improvement will be taken into account } \\
\text { to improve the module. }\end{array}$ \\
\hline
\end{tabular}

\section{Result \& discussion}

\subsection{Development of online module for acid and base topic based on $5 \mathrm{E}$ model}

Online module for acid and base topic based on 5E model has been developed to overcome the misconception in strength of acid and base topic. This module consists of two important part which is introduction of online module for acid and base topic based on 5E model and application of 5E model for strength of acid and base topic in online class. 
Introduction of online module for acid and base topic based on $5 \mathrm{E}$ model. In this part, teacher is introduced to the misconceptions that students often have in topic of strength of acid and base from previous literatures, objectives of the module and introducing steps required in implementing $5 \mathrm{E}$ model in teaching and learning process. There are several phases in 5E instructional model as shown in Figure 1.

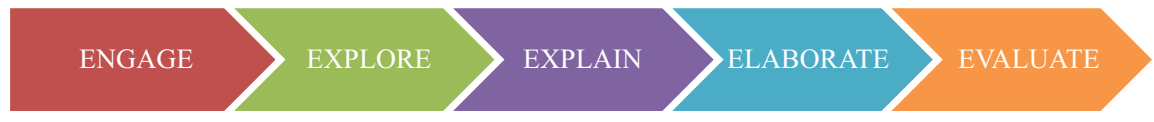

Fig. 1. Phases in $5 \mathrm{E}$ instructional model

Engage phase. The first phase of 5E instructional model is engage. In this phase, teacher need to attract students' interest in the concepts that will learned so that students will be eager to learn through interesting and meaningful activities. Teacher also needs to identify students' prior knowledge and any knowledge gaps [12]. In engage phase, firstly, the learning will be conducted using google meet. After that, the students will do experiment in their home using daily materials. Furthermore, the students are given questions that they must do it through Jamboard (Online board).

Explore phase. Explore phase need students to undergo concrete learning experience such as hands-on activity and interaction with materials. Activities designed in explore phase will provide experience to the students which can be utilized later during explanation. PhET Simulation is used to encourage students during exploring the strength of acid and base. In this situation, teacher acts as facilitator by asking probing questions and encourage students to participate in the activities [13].

Explain phase. Explain is a phase where teachers will assist students to synthesize new information or knowledge and students are encouraged to ask questions for clarification. Students will need to share their experience or finding from explore phase. To explain the task, the groups are suggested to do the task using PowerPoint or Prezi presentation. Then, teacher will introduce the concepts in a more scientific manner. Construction of new knowledge is gained as students compare the ideas that they obtain during explore phase with information obtained from the teacher. Students will organize this information and construct new knowledge.

Elaborate phase. In this phase, students need to apply what they have learned where the students need to relate the concepts with real life situation or similar concept in order to develop a deeper and broader understanding. Additional activities are conducted to apply their understanding on the concepts [12].

Evaluate phase. Evaluate is a phase where the extent of students' understanding on the concepts learned is assessed. Assessment examples such as self-assessment, formative assessment and summative assessment. Kahoot quiz and Jamboard are used to do evaluation of students. Multiple assessments can be used to evaluate the students [13]. 
Figure 2 and Figure 3 shows the display of module cover and introduction of online module for acid and base topic based on 5E model respectively.

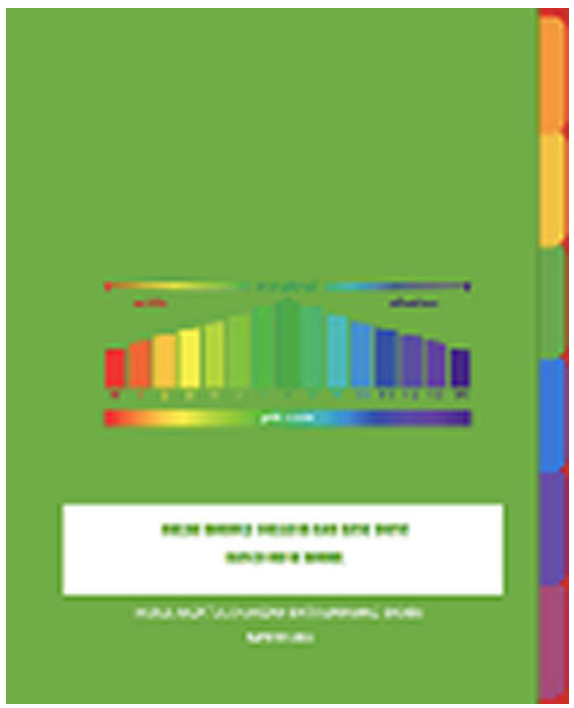

Fig. 2. Display of module cover of online module for acid and base topic based on 5 E model

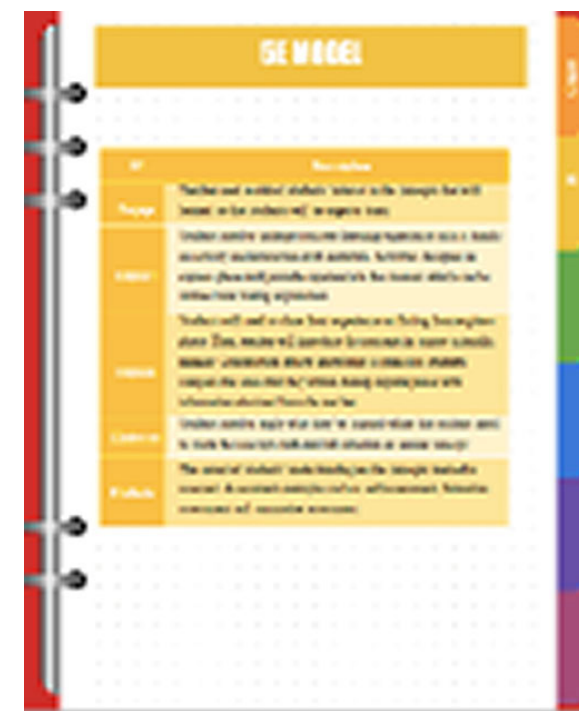

Fig. 3. Display of introduction of online module for acid and base topic based on 5 E model

Application of online module for acid and base topic based on $5 \mathrm{E}$ model. This part consists of application of 5E model for strength of acid and base topic in online class. Table 2 shows a lesson plan of online module based on $5 \mathrm{E}$ model for strength of acid and base topic. The activities of learning are according to five phases of 5E model.

Table 2. Lesson plan of online module for acid and base topic based on $5 \mathrm{E}$ model

\begin{tabular}{|c|c|}
\hline \multicolumn{2}{|c|}{ LESSON PLAN (ONLINE) } \\
\hline Subject: Chemistry & Form: 4 \\
\hline Topic: Strength of Acid and Base & Model of Learning: 5E Model \\
\hline \multicolumn{2}{|c|}{ Learning Outcomes } \\
\hline \multicolumn{2}{|l|}{ Students be able to: } \\
\hline \multicolumn{2}{|c|}{ 1) Determine the factor that affect the strength of acid and alkali } \\
\hline \multicolumn{2}{|c|}{$\begin{array}{l}\text { 2) Determine the differences between strong acid and weak acid and differences between strong base } \\
\text { and weak base }\end{array}$} \\
\hline \multicolumn{2}{|c|}{ 3) Draw the particles representation of strength of acid and base } \\
\hline \multicolumn{2}{|c|}{ 4) Relate the $\mathrm{pH}$ value with strength of acid and base } \\
\hline
\end{tabular}

(Continued) 
Table 2. Lesson plan of online module for acid and base topic based on 5E model (Continued)

\begin{tabular}{|c|c|c|c|}
\hline \multicolumn{4}{|c|}{ Activities of Learning } \\
\hline Phase & Activities & Materials Required & Time Allocation \\
\hline Engage & $\begin{array}{l}\text { Teacher ask students to give examples of acid } \\
\text { and base in daily life } \\
\text { Teacher and students will conduct home } \\
\text { experiment which is red cabbage pH test. } \\
\text { Activity } 1 \text { : } \\
\text { Students and teacher will make red cabbage pH } \\
\text { indicator. } \\
\text { Activity } 2 \text { : } \\
\text { Students will test household substances at their } \\
\text { home using the indicator produced and observe } \\
\text { the color changes } \\
\text { Students will determine the pH of household } \\
\text { substances using red cabbage pH scale } \\
\text { Teacher will give brief explanation that these } \\
\text { household substances have different strength of } \\
\text { acid and base } \\
\text { Students will write what they know about } \\
\text { strength of acid and base using jamboard }\end{array}$ & $\begin{array}{l}\text { Red cabbage, blender, } \\
\text { strainer, water, } \\
\text { container } \\
\text { Household substances } \\
\text { (lemon juice, vinegar, } \\
\text { shampoo, soap, milk, } \\
\text { baking soda and } \\
\text { others) } \\
\text { Red cabbage pH scale } \\
\text { Jamboard }\end{array}$ & 60 minutes \\
\hline Explore & $\begin{array}{l}\text { Students are divided into four groups and each } \\
\text { group will use PhET simulation to explore } \\
\text { about strength of acid and base } \\
\text { Group } 1 \text { and Group } 2 \text { will explore about strong } \\
\text { acid and weak acid } \\
\text { Group } 3 \text { and Group } 4 \text { will explore about strong } \\
\text { base and weak base } \\
\text { Students are asked to observe particles present, } \\
\text { particles representation, particles concentration, } \\
\text { pH and ionization equation for each solution } \\
\text { Students need to analyze and relate: } \\
\text { The pH changes with concentration of acid and } \\
\text { base } \\
\text { The pH changes with strength of acid and base } \\
\text { Students also can make additional research } \\
\text { about strength of acid and base from other } \\
\text { resources }\end{array}$ & $\begin{array}{l}\text { PhET simulation } \\
\text { https://phet.colorado. } \\
\text { edu/en/simulation/ } \\
\text { acid-base-solutions } \\
\text { Resources (books, } \\
\text { journals, educational } \\
\text { website) }\end{array}$ & 40 minutes \\
\hline Explain & $\begin{array}{l}\text { All groups are assigned to do PowerPoint or } \\
\text { Prezi presentation about what they learned } \\
\text { during PhET simulation exploration } \\
\text { Students need to present differences between } \\
\text { strength of acid and base in terms of particles } \\
\text { present, particles representation, particles } \\
\text { concentration, pH and ionization equation } \\
\text { Question and answer session is carried out } \\
\text { Teacher will give detailed explanations about } \\
\text { the concept of strength of acid and base } \\
\text { Teacher might give demonstration or show } \\
\text { videos for further understanding }\end{array}$ & $\begin{array}{l}\text { Microsoft PowerPoint } \\
\text { or Prezi } \\
\text { Video }\end{array}$ & $\begin{array}{l}1 \text { hour and } 20 \\
\text { minutes }\end{array}$ \\
\hline
\end{tabular}


Table 2. Lesson plan of online module for acid and base topic based on 5E model (Continued)

\begin{tabular}{|c|c|c|c|}
\hline \multicolumn{4}{|c|}{ Activities of Learning } \\
\hline Phase & Activities & Materials Required & Time Allocation \\
\hline Elaborate & $\begin{array}{l}\text { Students need to give daily life application of } \\
\text { strong and weak acid and base } \\
\text { Teacher give problems related to conductivity } \\
\text { Students need to relate conductivity with } \\
\text { strength of acid and base }\end{array}$ & Problem questions & 20 minutes \\
\hline Evaluate & $\begin{array}{l}\text { Teacher will conduct online Kahoot quiz } \\
\text { Students will write what they know about } \\
\text { strength of acid and base after the lesson } \\
\text { Students will fill in exit ticket }\end{array}$ & $\begin{array}{l}\text { Kahoot } \\
\text { Jamboard } \\
\text { Exit ticket }\end{array}$ & 20 minutes \\
\hline
\end{tabular}

Figure 4 and Figure 5 shows the display of activities in online module for acid and base topic based on 5E model in Engage phase and Explore phase respectively.

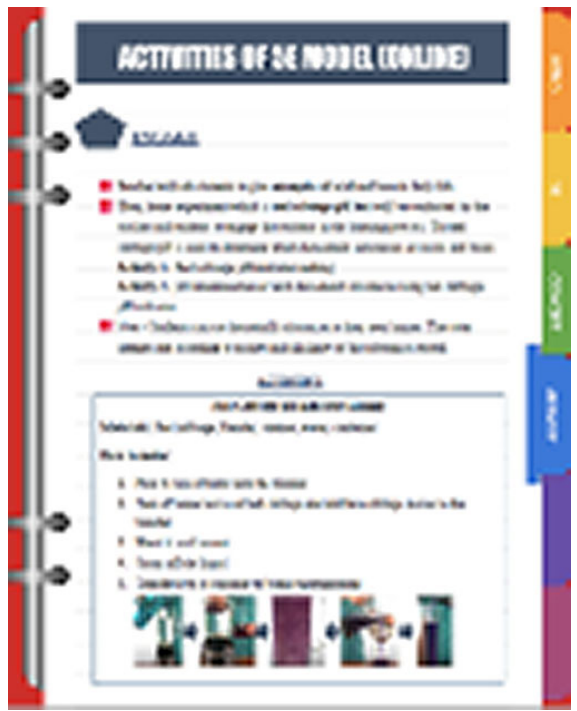

Fig. 4. Display of activities in online module for acid and base topic based on 5 E model in Engage phase

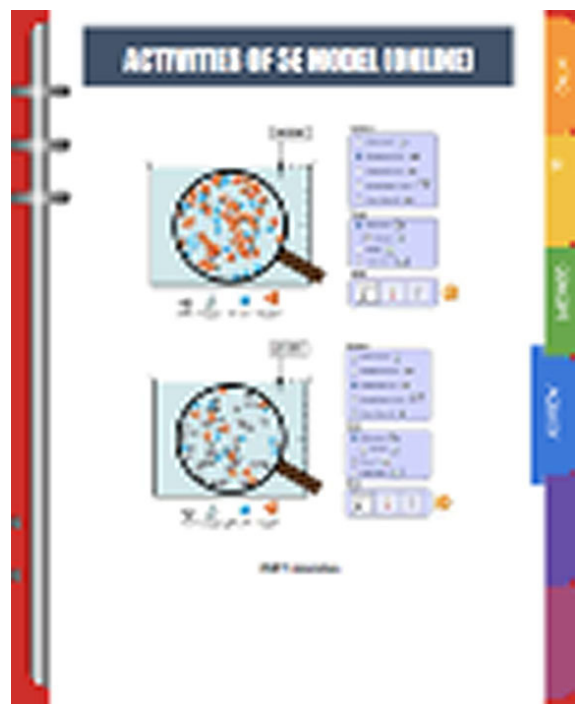

Fig. 5. Display of activities in online module for acid and base topic based on $5 \mathrm{E}$ model in Explore phase

Validation of the module. Validity is very significant in determining the suitability of a module to be implemented in teaching and learning process. Therefore, this module is validated to determine the suitability of the online module for acid and base topic based on $5 \mathrm{E}$ model developed. This module is validated by five experts in chemistry education field. These experts have experience in teaching chemistry in secondary school. A 5-point Likert scale survey from very poor to very good is used by the experts to validate the online module for acid and base topic based on 5E model. The module validity is evaluated in several aspects including module objectives, module content, usability, flexibility, language and learning activities. The validity of the module is 
calculated using percentage calculation method (PCM). The percentage of the score obtained for each aspect is calculated using formula as follows:

$$
\text { Percentage Score }=\frac{\sum \text { Gained score }}{\sum \text { Maximum score }} \times 100
$$

Table 3 shows the validation results of module validation from the experts while Figure 6 shows the validation results from the experts in the form of graph.

Table 3. Analysis of validation results from expert

\begin{tabular}{|c|l|c|l|}
\hline No. & \multicolumn{1}{|c|}{ Aspects } & Percentage Score (\%) & \multicolumn{1}{|c|}{ Interpretation } \\
\hline 1 & Objectives & 88.0 & Very Good \\
\hline 2 & Content & 84.0 & Very Good \\
\hline 3 & Usability & 86.7 & Very Good \\
\hline 4 & Flexibility & 92.0 & Very Good \\
\hline 5 & Language & 96.0 & Very Good \\
\hline 6 & Learning activities & 94.0 & Very Good \\
\hline & Average & 90.1 & Very Good \\
\hline
\end{tabular}

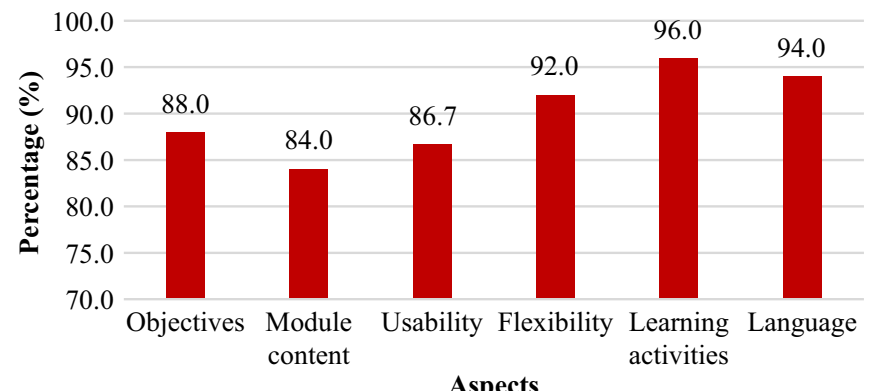

Fig. 6. Validation results from experts

Based on the results from the survey, the percentage scores obtained are $88 \%, 84 \%$, $87 \%, 92 \%, 96 \%$ and $94 \%$ in module objectives, module content, usability, flexibility, learning activities and language aspects respectively. Based on interpretation of 5 points-likert scale, the results show that this module is very good in terms of all aspects evaluated as it achieves more than $80 \%$. Overall percentage score average for the module validity is $90.1 \%$ which indicates that this module is very good and has high validity in general. Therefore, this module is feasible and suitable to be implemented to overcome students' misconception on strength of acid and base topic

In module objective aspect, it shows that the module fulfills the objectives stated which is to fix the misconception and enhance students' understanding in strength of acid and base topic. The content of this module is also considered feasible. It is aligned with the intended learning outcomes in curriculum. The teaching steps and evaluation provided in this module also complete where it can be used as a guideline to the teacher when implementing $5 \mathrm{E}$ model in online teaching and learning process. The contents of 
this module are enough for students to understand strength of acid and base topic. This finding is in line with the study of [13] who found that the module developed using the $5 \mathrm{E}$ model was found to be able to correct students' misconceptions.

For usability aspect, 5E model is suitable to be used in teaching and learning process of strength of acid and base topic. The activities proposed also suitable to be used in online class and the content of this module can be delivered easily to the students. In terms of learning activities, the teaching strategies are in alignment with $5 \mathrm{E}$ instructional model and it can trigger the activeness of students' participation in learning chemistry. This module is flexible as it can be used by any party to teach the students. The language used in this module also easy to understand. This finding is in line with [14] study which showed that active learning occurs and effective teaching can be implemented using modules developed based on appropriate models as well as using clear language.

There are several suggestions that has been made by the experts to improve the module in terms of appearance and content. It is suggested by the experts to put more infographic in some parts to make the module more interesting and change color of the module cover. The usage of the image also needs to be in high definition or high pixel to ensure the image is clear when this module is copied. There are also minor corrections that need to be done such as wording and grammar. Explanation on certain tools used in the module also need to be explained as not all teachers are familiar with the tools. In evaluation phase, it is suggested to include structured questions to ensure that students can completely understand the concepts and overcome the misconception on strength of acid and base especially for underachiever students. Learning video during explain phase are also suggested to be included. This finding is in line with the study of [15] who suggested that the use of video, graphics and images can help the learning process more effectively, including overcoming the existence of student misconceptions.

Advantages of modules. There are various advantages that students and teachers can gain through the use of $5 \mathrm{E}$ model of online teaching and learning module.

Teacher. This module provide teacher with insights on how to identify the misconception that students have for strength of acid and base topic, what kind of activities that can be implemented in online class to overcome the misconception and how to engage students in the learning process. Novice or beginner teachers can also enhance their teaching process as this module incorporates step by step stages. Lastly, teacher can evaluate own teaching method used from the exit ticket answered by the students. Improvement on teaching method or learning activities can be made.

Students. Firstly, the learning process become more student-centered as students are actively engaged in the learning process. The activities proposed in this module can result in better acquisition of scientific concepts compared to traditional teaching method as simulation is used to enable students to visualize the particles present in microscopic level. Students construct their own knowledge by exploring the learning activities and having discussion with peers which encourage them to use their inquiry and critical thinking. As a result, their cognitive skills are improved. The activities also allow students to relate new knowledge gained with prior knowledge which can lead to meaningful learning.

Learning media. This module can be a learning media that is suitable to use in online learning. It is accessible using mobile phone, tablet, and PC. The activities provided 
makes students having interactive learning environment. Thus, this module can be used during COVID-19 pandemic as learning media.

\section{Conclusion}

Strength of acid and base is a difficult topic and often causes misconception among students. Therefore, 5E instructional model is applied in this online teaching and learning module to overcome these misconceptions and better understanding on this topic. The result of the study shows that the module is very valid and has high suitability to be implemented in teaching and learning process. Improvement needs to be made to ensure that this module can be implemented effectively and be used by any party. Besides, the use of interactive media and tools in module help students being interactive during online learning. This module is also accessible using any mobile phones, PC, and electronic devices. It is hoped that this module can be implemented in actual class and can be as a guideline for module development for another topic which students have misconception on. Improvement should be made to enhance the effectiveness.

\section{$5 \quad$ Acknowledgment}

The authors would like to thank Universiti Teknologi Malaysia (UTM) for their support in making this project possible. This work was supported by the Research University Grant (Q.J130000.2453.09G35 and Q.J130000.2509.21H20) initiated by UTM.

\section{References}

[1] Cetin-Dindar, A., \& Geban, O. (2016). Conceptual understanding of acids and bases concepts and motivation to learn chemistry. The Journal of Educational Research, 1-13. https:// doi.org/10.1080/00220671.2015.1039422

[2] Demircioğlu, G., \& Çağatay, G. (2014). The effect of laboratory activities based on 5E model of constructivist approach on 9th grade students' understanding of solution chemistry. Procedia - Social and Behavioral Sciences, 116, 3120-3124. https://doi.org/10.1016/j. sbspro.2014.01.719

[3] Putra, F., Nurkholifah, I. Y., Subali, B., \& Rusilawot, A. (2018). 5E-learning cycle strategy: increasing conceptual understanding and learning motivation. Journal Ilmiah Pendidikan Fisika Al-Biruni, 7(2), 171-181. https://doi.org/10.24042/jipfalbiruni.v7i2.2898

[4] Artdej, R., Ratanaroutai, T., Coll, R. K., \& Thongpanchang, T. (2010). Thai Grade 11 students' alternative conceptions for acid-base chemistry. Research in Science \& Technological Education, 28(2), 167-183. https://doi.org/10.1080/02635141003748382

[5] Lathifa, U. (2018). Correcting students' misconception in acid and base concept using PDEODE instruction strategy. Unnes Science Education Journal, 7. https://doi.org/10.15294/ usej.v7i2.23202

[6] Demircioglu, G., Ayas, A., \& Demircioglu, H. (2005). Conceptual change achieved through a new teaching program on acids and bases. Chemistry Education Research and Practice, 6(1), 36-51. https://doi.org/10.1039/B4RP90003K 
[7] Sheppard, K. (2006). High school students' understanding of titrations and related acidbase phenomena. Chemistry Education Research and Practice, 7. https://doi.org/10.1039/ B5RP90014J

[8] Mubarokah, F. D., Mulyani, S., \& Indriyanti, N. Y. (2018). Identifying students' misconceptions of acid-base concepts using a three-tier diagnostic test: a case of indonesia and thailand. Journal of Turkish Science Education, 15(Special), 51-58.

[9] Apriwanda, N. W., Mahanan, M., Ibrahim, N., Surif, J., Osman, S., \& Bunyamin, M. (2021). Dual mode module as new innovation in learning chemistry: project based learning oriented. International Journal Of Interactive Mobile Technologies (IJIM), 15(18), 47-64. https://doi. org/10.3991/ijim.v15i18.24549

[10] Bretz, S. L., \& McClary, L. (2015). Students' understandings of acid strength: how meaningful is reliability when measuring alternative conceptions? Journal of Chemical Education, 92(2), 212-219. https://doi.org/10.1021/ed5005195

[11] Khalil, M. K., \& Elkhider, I. A. (2016). Applying learning theories and instructional design models for effective instruction. Advances in Physiology Education, 40(2), 147-156. https:// doi.org/10.1152/advan.00138.2015

[12] Alshehri, M. A. (2016). The impact of using (5E's) instructional model on achievement of mathematics and retention of learning among fifth grade students. OSR Journal of Research \& Method in Education, 6(2), 43-48.

[13] Hu, J., Gao, C., \& Liu, Y. (2017). Study of the 5E instructional model to improve the instructional design process of novice teachers. Universal Journal of Educational Research, 5(7), 1257-1267. https://doi.org/10.13189/ujer.2017.050718

[14] Surif, J., Ibrahim, N. H., Alwi, A. M., Loganathan, P., \& Serman, N. S., "Effect of Inductive Teaching Method To Improve Science Process Skills In Electrochemistry," 2019 IEEE International Conference on Engineering, Technology and Education (TALE), 2019, 1-5. https:// doi.org/10.1109/TALE48000.2019.9225869

[15] Samat, N. A., Ibrahim, N., Surif, J., Ali, M., Halim, A., Abdullah, Talib, C. A., \& Bunyamin, M. A. (2019). Chem-a module based on stem approach in chemical bond. International Journal of Recent Technology and Engineering (IJRTE), 7, 6S5, 700-708.

[16] Ramli, A. A., Ibrahim, N. H., Surif, J., Bunyamin, M. A. H., Jamaluddin, R., \& Abdullah, N. (2017). Teacher readiness in teaching STEM education. Man In India, 97 (13), 343-350.

\section{Authors}

Nurul Nazatul Shahizah Mahamd Shobri is a student of Master of Education (Chemistry), School of Education, Faculty of Social Science and Humanities, Universiti Teknologi Malaysia, Johor Bahru, Malaysia, 81310. She received Bachelor of Engineering (Chemical) from Universiti Teknologi Malaysia. Her current research interest is about computational skills in chemistry education (email: nazatulshahizah.09@, gmail.com).

Johari Surif is associate professor in Department of Educ Science, Mathematics and Multimedia Creative, Faculty of Science Social and Humanities, Universiti Teknologi Malaysia, Johor Bahru, Malaysia, 81310. He received Bachelor in Environmental Sciences from Universiti Kebangsaan Malaysia, Master's Degree and Doctor of Philosophy in Chemistry Education from Universiti Teknologi Malaysia. His research interest is regarding science education, chemistry education and STEM education. He also currently actively involved in research and programs related to STEM education, community and many more (email: johari surif@utm.my). 
Nor Hasniza Ibrahim is senior lecturer in Department of Educ Science, Mathematics and Multimedia Creative, Faculty of Science Social and Humanities, Universiti Teknologi Malaysia, Johor Bahru, Malaysia, 81310. She received her Bachelor in Biomedical Sciences from Universiti Putra Malaysia, Master's Degree and Doctor of Philosophy in Chemistry Education from Universiti Teknologi Malaysia. Her research interest is regarding science education, chemistry education and STEM education. She now works as senior lecturer in She also currently actively involved in research and programs related to STEM education and indigenous people (email: p-norhaniza@utm.my)

Wimbi Apriwanda Nursiwan is student of Master of Education (Chemistry), School of Education, Faculty Social Science and Humanities, Universiti Teknologi Malaysia, Johor Bahru, Malaysia, 81310. She received Bachelor of Education (Chemistry) from Universitas Riau, Indonesia and carried out research focusing on Diagnostic Test Based on Attribute Hierarchy Method (AHM), and now her research interest is about scientific creativity in chemistry education (email: wimbiiapriwanda@gmail.com).

Muhammad Abd Hadi Bunyamin is a senior lecturer at School of Education, Universiti Teknologi Malaysia (UTM). He obtained his Bachelor's and Master's degrees in Physics Education from UTM and PhD from the University of Minnesota, the United States. He has been doing research in STEM education especially physics teaching and learning and cultural studies in STEM in the settings of school and higher education. He currently involves in physics teaching and learning at a secondary school in Johor, Malaysia in a long-term professional development program (email: mabhadi@, utm.my).

Article submitted 2021-09-07. Resubmitted 2021-10-19. Final acceptance 2021-10-19. Final version published as submitted by the authors. 